\title{
SOCIO-ECONOMIC AND ENVIRONMENTAL ASPECTS OF THE INDUSTRY IMBALANCES IN THE REGIONAL ECONOMY
}

The paper presents an analysis of current socio-economic and environmental aspects of the industry imbalances in the regional economy by the example of Ural Federal District and Siberian Federal District. The main aim of it is to identify the actual socio-economic problems in the development of the regional economies.

The authors analyze the economic, ecological and social aspects in the development of regional economies by the examples. They investigate the specifics of the correlation between industrial development, ecological problems and health problems of the local population. Particular emphasis is placed on the analysis of correlations between the mortality of the population and industrial pollution of air and water.

The analysis has resulted in making proposals for optimization of the regional policy in the field of investments, manufacturing and ecology. The special attention is given to environment-oriented projects.

The most practicable way in solving the problem of these regional industry imbalances would be the development of regional diversification programs of the Siberia and the Ural economies. It has to support manufacturing and the largest public-private investment projects for the foundation of enterprises in agriculture, food and other industries. The most prosperous among them is the direction of bioenergy and forest-engineering-oriented businesses.

The results of the research can be useful in solving the problem of the industry imbalances in the regional economic policy of the Russian Federation.

Keywords: industry imbalances, regional economy, ecological problems, industrial pollution, population 


\section{Introduction}

The territory of the Russian Federation is enormous. The international division practice demonstrates the structuring feasibility of the national economy by the macro-regions. The division of Russia by federal districts occurred in 2000 with the signing of the decree of the President «On the Representative of the President of the Russian Federation in the Federal District.» In accordance with the Decree on the territory of Russia, there were created seven federal districts - the Central, North-Western, Southern, Volga, Ural, Siberian and Far East. In 2011, the Southern Federal District was divided into two - Southern and Northern Caucasus. The creation of the districts according to experts, should in the future increase the effectiveness of state regulation of social and economic development of the regions of the country, also by the way of working out the programs of socio-economic development of territories by the Federal District [1], [ 2].

However, the problem of uneven development of Russian territories remains, it has not been solved till now. In the western part of Russia most of the country population is located, there are significant differences in the palette of industries: in Siberia, the Ural and the Far East mining industry and forestry dominate; in the Central, Volga, Southern, North-Caucasian, North-Western districts processing production, processing industry and agriculture are popular. By the opinion of many Russian scientists, «slide area to the commodity slope» has significant socio-economic and demographic risks. In addition, in the Siberian (the SFO) and the Ural (the UFD) federal districts, which are the focus of our research, there are large areas of uncultivated land, which involvement into the economic cycle is the most important socio-economic and geopolitical task because in recent times in this area increased attention is paid to the densely populated region from neighboring countries, such as China.

\section{Theoretical basis of the research}

Modern economists often discuss the problem of uneven development of regions and sectors against the background of the cyclical fluctuations of the economy. There is an extensive body of evidence showing an indispensable worsening crisis trends in the national economy, which domestic economy is developing unevenly. As you know, increases, like phases of long waves, are provoked by considerable innovative impulses. The Russian scientist N. Kondratiev observed the empirical correctness accompanying long economic cycles, «For about two decades before the start of an upward wave of the big cycle there is a revival in the field of technical inventions. Before and at the beginning of an upward wave a widespread use of these inventions is observed...» [3, p. 374]. This idea has received active development in the works of Y. Schumpeter who saw an explanation of the reason of long economic cycles in the waves of technological innovation. Empirical evidence linking long-wave production and innovation are found in the works of the Russian scientists Yu. V. Yakovets, S. Glazev, A. Akaev and their foreign counterparts G. Mensch, E. Denison. This approach connects each Kondratiev wave with a certain technological way of life. The researchers point out that the rise of a new wave of development is damped if there are sector imbalances in the national economy, and in this case the new technological system may not come in time.

The Russian economists such as D. Lvov and S. Glazev introduced the concept of a technological system in the economic terminology. Technological system is a set of technologies specific to a particular level of production, scientific and technological progress. It is continuously moving the economy from a lower to a higher way of life, the basis of subsequent technological system originates in the period of flowering and the previous order.

The Russian sectors of the economy are substantially integrated among themselves and organically integrated into the global economy, so the processes of globalization (including information), computer and Internet penetration have a seminal role. At the end of the XX century an important role was played by information technologies: devices and technologies for the collection, processing, transfer of information, technology and satellite navigation. Universal computerization of production processes and management, the use of mobile electronic communication were a breakthrough for the industry but are still not available on a mass scale for the rural economy of our country.

We believe that in order to speed up the process of innovation development of the entire national economy it is necessary to eliminate inequality in the development of individual sectors and regions. In the opinion of the authors of Moscow State University, who worked on the major project, «World Economic Thought. Through the Prism of the Century» coordinated by G. Fetisovaand, A. Hudokormova, agro-industrial country like Russia, it is necessary to maintain a balance between industry and agriculture as the development of one sector is a prerequisite for the development of the other [4, p. 625]. 


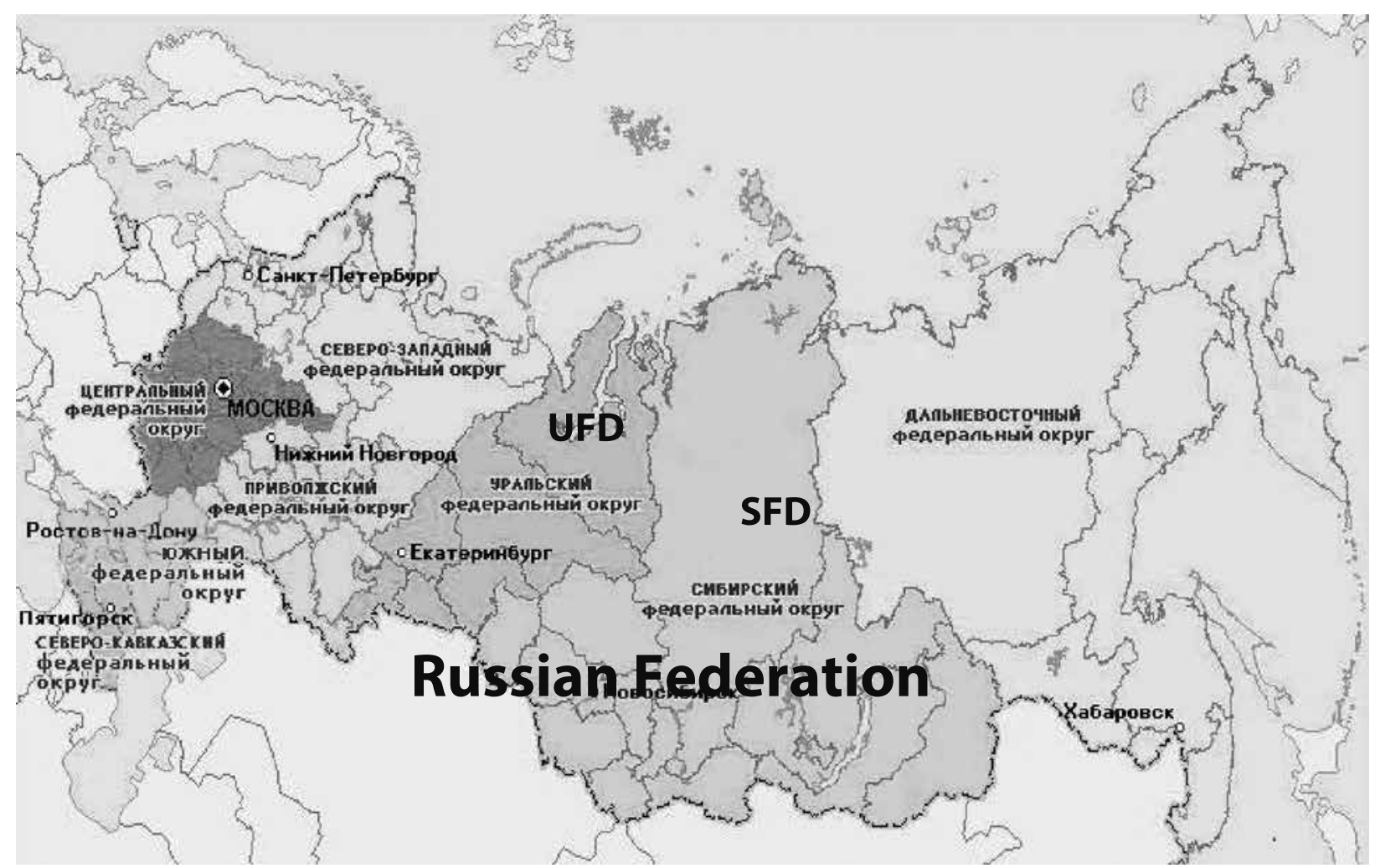

Fig. 1. Federal districts of the Russian Federation

Data of UFD and SFD

The total area of SFD and UFD takes more than $1 / 3$ of Russia, and plays an important role in the socio-economic processes in the country (Fig. 1).

Indicators of Table 1 give an overview of the socio-economic development of the SFD and the UFD. In recent years, the Siberian Federal District has demonstrated lower GRP growth rate in comparison with the Ural Federal District and against the background of the national economy as a whole. At the same time, there is a decrease in the number of the SFD (for the pe-

Table 1

Socio-economic indicators of the federal districts 2000-2012 [3]

\begin{tabular}{|c|c|c|c|c|c|c|c|}
\hline Indicators & unit & $\begin{array}{l}\text { Russia/ Federal } \\
\text { Districts }\end{array}$ & 2000 & 2005 & 2010 & 2012 & $\begin{array}{l}\text { Growth rate } \\
(2012 / 2000)\end{array}$ \\
\hline \multirow{3}{*}{$\begin{array}{l}\text { Gross Regional Product } \\
\text { (Russia-GDP) (at current } \\
\text { prices) }\end{array}$} & \multirow{3}{*}{ mln rub. } & Russia & 7305600 & 21609800 & 46308500 & 62599100 & 8,57 \\
\hline & & UFD & 866133 & 3091363 & 5118918 & 6398648 & 7,39 \\
\hline & & SFD & 687070 & 1951299 & 4093589 & 4767595 & 6,94 \\
\hline \multirow{3}{*}{ Population } & \multirow{3}{*}{$\begin{array}{l}\text { thous. } \\
\text { people }\end{array}$} & Russia & 146300 & 143800 & 142900 & 143000 & 0,98 \\
\hline & & UFD & 12515 & 12279 & 12081 & 12143 & 0,97 \\
\hline & & SFD & 20333 & 19495 & 19252 & 19267 & 0,95 \\
\hline \multirow{3}{*}{$\begin{array}{l}\text { The gross regional product } \\
\text { per } 1 \text { person of population } \\
\text { (at current prices) }\end{array}$} & \multirow{3}{*}{ rub. } & Russia & 39532 & 126014 & 226007 & 305512 & 7,73 \\
\hline & & UFD & 69327 & 254078 & 423495 & 372367 & 5,37 \\
\hline & & SFD & 33682 & 99628 & 212440 & 266492 & 7,91 \\
\hline \multirow{3}{*}{$\begin{array}{l}\text { The average annual } \\
\text { number of the employed } \\
\text { in the economy }\end{array}$} & \multirow{3}{*}{$\begin{array}{l}\text { thous. } \\
\text { people }\end{array}$} & Russia & 65070 & 68339 & 69933 & 71545 & 1,10 \\
\hline & & UFD & 5720 & 6019 & 6005 & 6159 & 1,08 \\
\hline & & SFD & 8691 & 8912 & 9027 & 9020 & 1,04 \\
\hline \multirow{3}{*}{ The unemployment rate } & \multirow{3}{*}{$\%$} & Russia & 10,6 & 7,1 & 7,3 & 5,5 & - \\
\hline & & UFD & 10,1 & 6,7 & 8 & 6 & - \\
\hline & & SFD & 12,8 & 9,3 & 8,7 & 7,1 & - \\
\hline \multirow{3}{*}{ The immigration rate } & \multirow{3}{*}{$\begin{array}{c}\text { people } \\
\text { per } 10.000 \\
\text { people of } \\
\text { population }\end{array}$} & Russia & 16 & 9 & 13 & 22 & 1,38 \\
\hline & & UFD & 6 & 8,2 & 9 & 31 & 5,17 \\
\hline & & SFD & -15 & -8 & -3 & 1 & 16 \\
\hline
\end{tabular}


Production industries (mining, agriculture and forestry) [3]

\begin{tabular}{|c|c|c|c|c|c|c|c|}
\hline Indicators & unit & \begin{tabular}{|c|} 
Russia/ Federal \\
Districts \\
\end{tabular} & 2000 & 2005 & 2010 & 2012 & $\begin{array}{l}\text { Growth rate } \\
(2012 / 2000)\end{array}$ \\
\hline \multirow{3}{*}{$\begin{array}{l}\text { Production of extractive } \\
\text { industries }\end{array}$} & \multirow{3}{*}{ mln rub. } & Russia & 2391000 & 3063000 & 6227000 & 8031000 & 3.36 \\
\hline & & UFD & 441728 & 1698000 & 2525000 & 3156000 & 7.14 \\
\hline & & SFD & 248000 & 318000 & 886000 & 1156000 & 4.66 \\
\hline \multirow{3}{*}{$\begin{array}{l}\text { Extraction of oil and gas } \\
\text { condensate }\end{array}$} & \multirow{3}{*}{ thous. t. } & Russia & 323517 & 414422 & 505326 & 631587 & 1.95 \\
\hline & & UFD & 213253 & 320237 & 307051 & 310429 & 1.46 \\
\hline & & SFD & 7930 & 18667 & 29404 & 29727 & 3.75 \\
\hline \multirow{3}{*}{$\begin{array}{l}\text { Production of natural and } \\
\text { associated gas }\end{array}$} & \multirow{3}{*}{$\operatorname{mln} \mathrm{m}^{3}$} & Russia & 583878 & 617601 & 651323 & 658487 & 1.13 \\
\hline & & UFD & 583359 & 585311 & 572295 & 578590 & 0.99 \\
\hline & & SFD & 3005 & 4708 & 6410 & 6481 & 2.16 \\
\hline \multirow{3}{*}{ Coal mining } & \multirow{3}{*}{ thous. $\mathrm{t}$. } & Russia & 258287 & 289994 & 321701 & 414932 & 1.61 \\
\hline & & UFD & 6684 & 4419 & 2154 & 2692 & 0.40 \\
\hline & & SFD & 193746 & 231324 & 268902 & 350966 & 1.81 \\
\hline \multirow{3}{*}{ Agricultural production } & \multirow{3}{*}{ mln rub. } & Russia & 742424 & 1380961 & 2587751 & 4011695 & 5.40 \\
\hline & & UFD & 47313 & 97487 & 175396 & 202061 & 4.27 \\
\hline & & SFD & 119798 & 201468 & 386838 & 506028 & 4.22 \\
\hline \multirow{3}{*}{ Gross grain } & \multirow{3}{*}{ thous. $\mathrm{t}$. } & Russia & 65400 & 77800 & 61000 & 91300 & 1.40 \\
\hline & & UFD & 3908 & 4810 & 3339 & 2514 & 0.64 \\
\hline & & SFD & 12838 & 11648 & 13355 & 14801 & 1.15 \\
\hline \multirow{3}{*}{ Gross harvest of potatoes } & \multirow{3}{*}{ thous. $\mathrm{t}$. } & Russia & 29500 & 28100 & 21100 & 31700 & 1.07 \\
\hline & & UFD & 2224 & 2677 & 1220 & 1533 & 0.69 \\
\hline & & SFD & 5274 & 4944 & 5479 & 5951 & 1.13 \\
\hline \multirow{3}{*}{$\begin{array}{l}\text { Production of meat and meat } \\
\text { products }\end{array}$} & \multirow{3}{*}{ thous. t. } & Russia & 4446 & 4990 & 7167 & 7628 & 1.72 \\
\hline & & UFD & 345 & 371 & 525 & 551 & 1.60 \\
\hline & & SFD & 751 & 827 & 1046 & 1112 & 1.48 \\
\hline \multirow{3}{*}{ Production of milk } & \multirow{3}{*}{ thous. t. } & Russia & 32259 & 31069 & 31847 & 31744 & 0.98 \\
\hline & & UFD & 2293 & 1952 & 2096 & 4101 & 1.79 \\
\hline & & SFD & 5575 & 5447 & 5629 & 5931 & 1.06 \\
\hline \multirow{3}{*}{ Production of eggs } & \multirow{3}{*}{ mln pcs. } & Russia & 34085 & 37140 & 40599 & 42093 & 1.23 \\
\hline & & UFD & 3521 & 4015 & 4064 & 4153 & 1.18 \\
\hline & & SFD & 5003 & 5448 & 5838 & 6027 & 1.20 \\
\hline \multirow{3}{*}{ Reforestation } & \multirow{3}{*}{ thous. hectars } & Russia & 972,9 & 812,3 & 811,5 & 860 & 0.88 \\
\hline & & UFD & 64,3 & 58,3 & 63,8 & 63 & 0.98 \\
\hline & & SFD & 286,2 & 222,6 & 225,1 & 238 & 0.83 \\
\hline \multirow{3}{*}{ Timber manufacture } & \multirow{3}{*}{ thous. $\mathrm{m}^{3}$} & Russia & 80600 & 98200 & 112200 & 120500 & 1.50 \\
\hline & & UFD & 5747 & 5465 & 5861 & 5390 & 0.94 \\
\hline & & SFD & 17326 & 24791 & 32255 & 39618 & 2.29 \\
\hline
\end{tabular}

riod 2000-2012 years decrease made $9.5 \%$ and $9.8 \%$ in Russia). Against this background picture of the dynamics of the population, the UFD is more stable (for 12 years, it has decreased by $3 \%)$.

Performance indicators GRP per capital are presented in Figure 2 and the unemployment rate (Table 1) also illustrates a positive trend in the Urals in comparison with Siberia.

The gross regional product per 1 person of the population of the Ural during the analyzed period exceeds the same indicator of Russia and Siberia. Details of it by production of such industries as mining, agriculture and forestry presented in Table 2. In 2012, this surplus was 1.2 times the Russian level and 1.4 times compared to the SFD, but the rate of growth since 2000 in the UFD and
SFD have been below the national average. In the UFD, the active migration of the population is observed (in 2012 net migration rate is 1.4 times as high as the value for the whole country).

We can see that there is a tendency of growth of extractive industries and also in agricultural production in SFD and SFD (Table 2).

\section{Analysis of UFD and SFD}

Production of the extractive industries in the Ural and Siberian Federal District was actively growing from 2000 to 2012 year. The growth rate of mining in natural units in Siberia and the Ural during the last 12 years was significantly higher than that the same rate of Russia. Thus, oil production in the SFD and UFD increased by 3.8 and 1.5 times respectively (Fig. 3). 


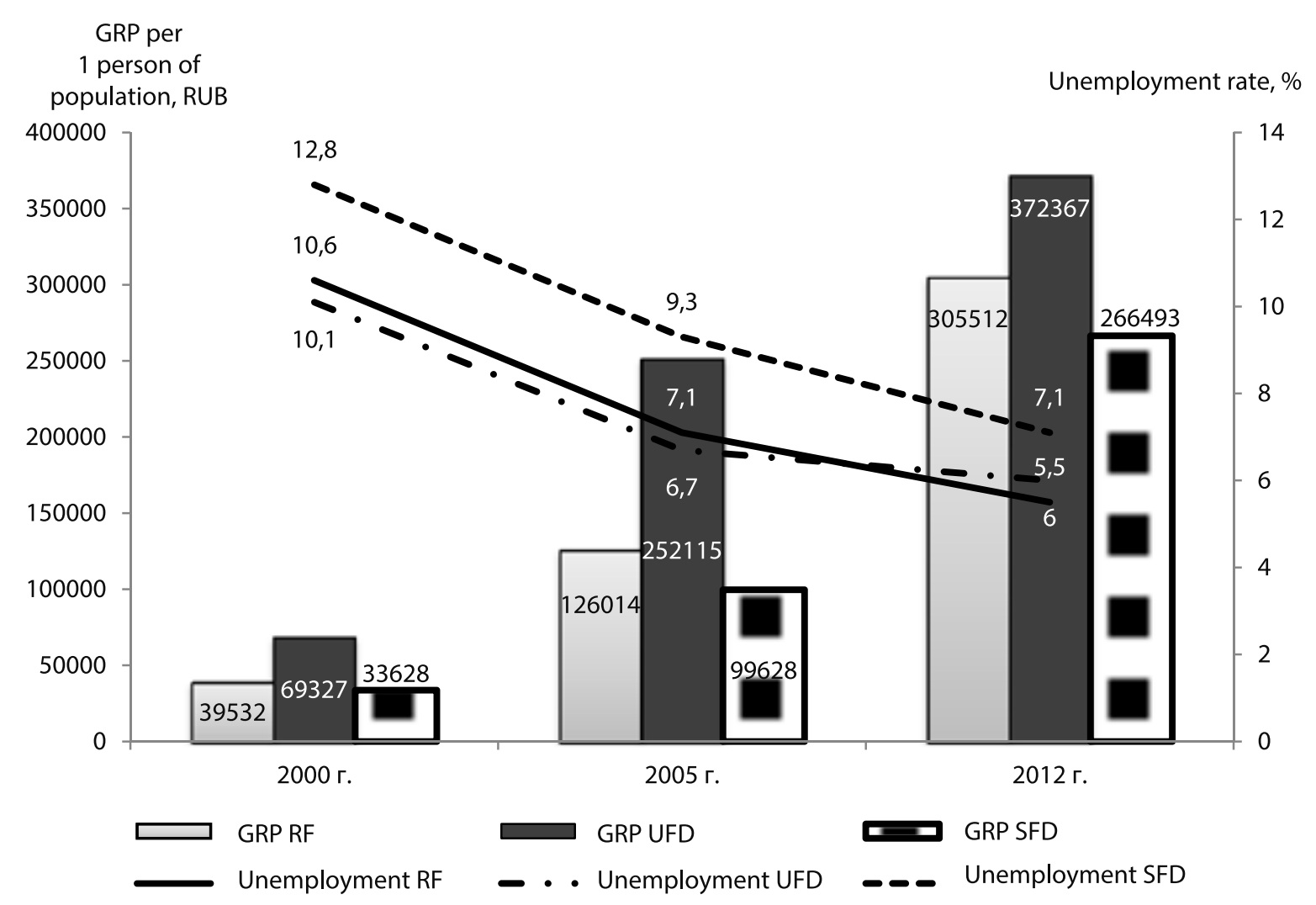

Fig. 2. Dynamics of the gross regional product per 1 person of population and unemployment rate

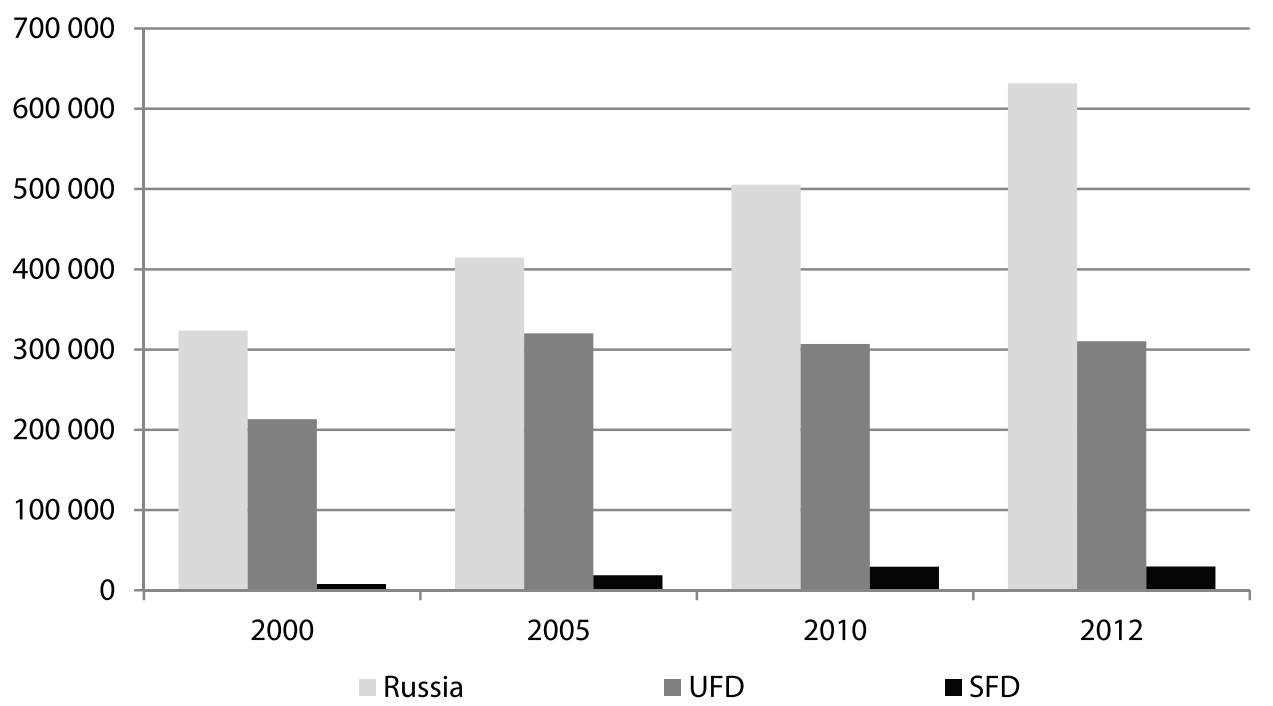

Fig. 3. Percentage of the UFD and the SFD in the total oil production in the economy of Russia (thous. tons)

In Siberia, we can observe the significant increase in coal mining - by 1.8 times (Fig. 4), in gas production -2.2 . (Fig. 5), timber production - by 2.3 times (Fig. 6).

At the same time, agricultural output in value terms (corn, potatoes, meat, eggs) in the Ural and Siberian Federal District is growing more slowly than the average for Russia. Only milk production in the Ural Federal District has increased by 1.8 times since 2000 against the background of «frozen» value of milk production in Russia (32 million tons). That clearly demonstrates the industry imbalance in the economy of our coverage of the federal districts.

Over the decade, there has been an increase in the proportion of the Urals and Siberia in the mining sector of the national economy - more than half of all oil country, a third of the wood, most of the gas (UFD) and coal (SFD) are produced here.

To identify the closeness of the connection between the indices of mortality, disease, indicators of industrial pollution into the air and water, we have performed a correlation analysis of the indicators in Table 3, which operates the following in- 


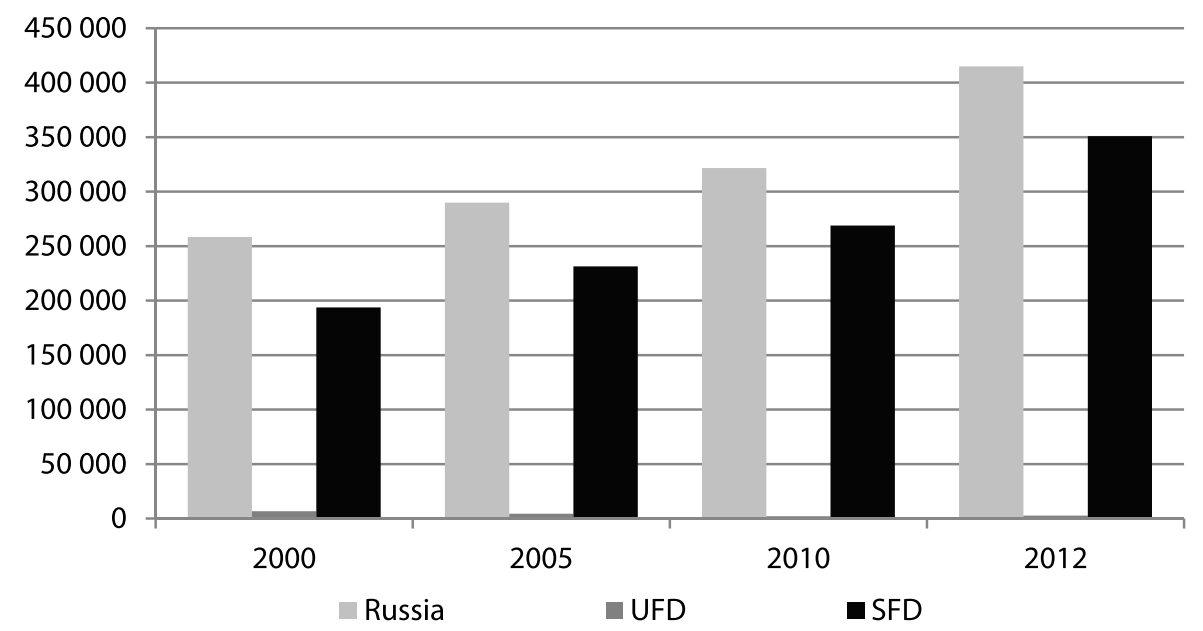

Fig. 4. Percentage of the UFD and the SFD in the coal mining in the economy of Russia (thous. tons)

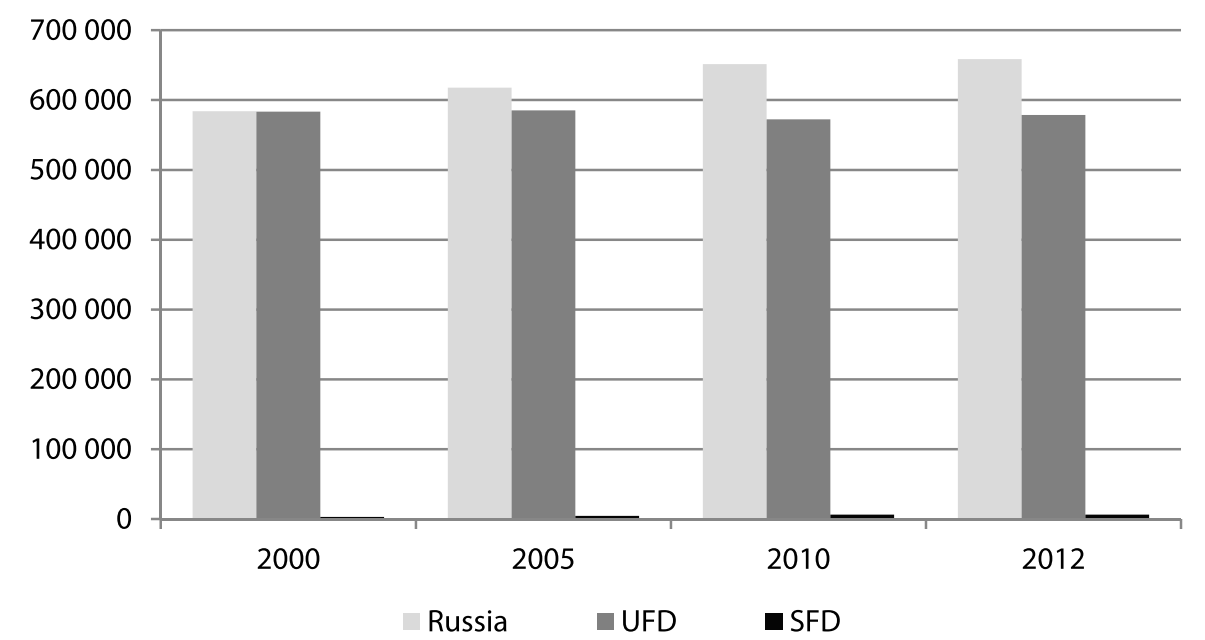

Fig. 5. Percentage of the UFD and the SFD in the total gas production in the economy of Russia ( $\mathrm{m} / \mathrm{n} \mathrm{m} 3)$

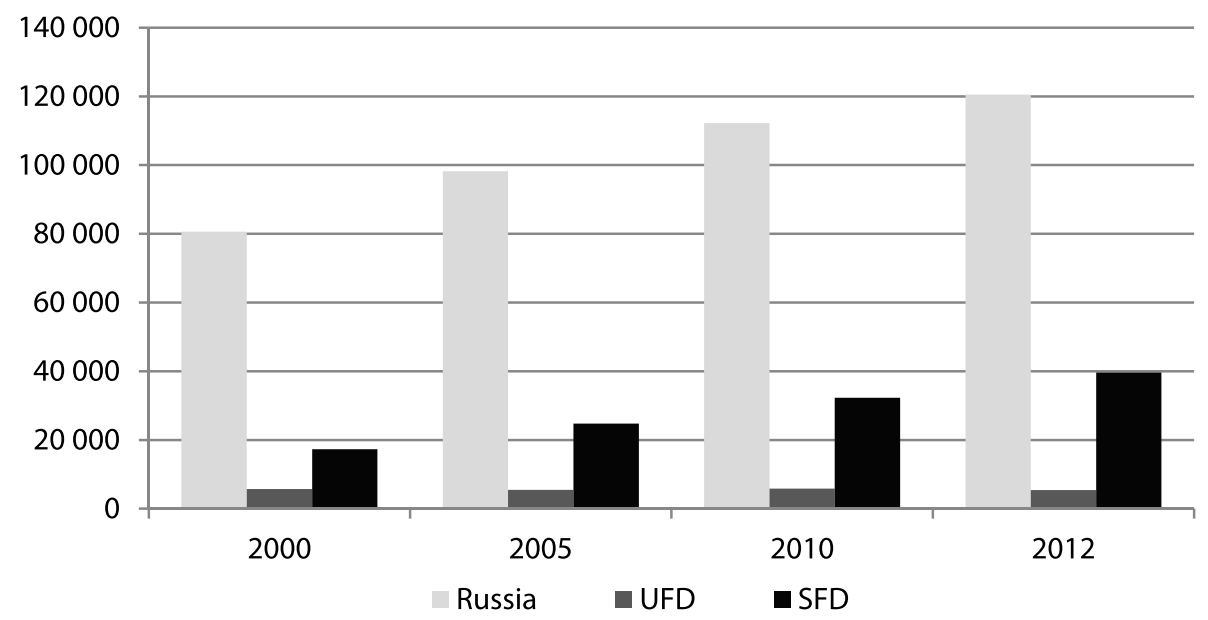

Fig. 6. Percentage of the UFD and the SFD in the total timber production in the economy of Russia (thous. $\mathrm{m}^{3}$ )

dexes: population mortality rates $(\mathrm{K} \mathrm{pp})$, correlation coefficients of mortality to industrial pollution of the air (KK c-ap) and water (KK c-wp), correlation coefficients of disease in population with industrial pollution of the air KK d-ap) and correlation coefficients of disease in populations with water pollution (KK d-wp).
The results of the correlation analysis are as following: for the UFD correlation coefficients of pairs of indicators KK c-ap -0.43 , KK c-wp -0.94 , KK d-ap -0.42 , KK d-wp -0.85 , for the SFD correlation coefficients of pairs of indicators KK c-ap -0.74 , KK c-wp -0.45 , KK d-ap -0.89 , KK d-wp -0.98 . 


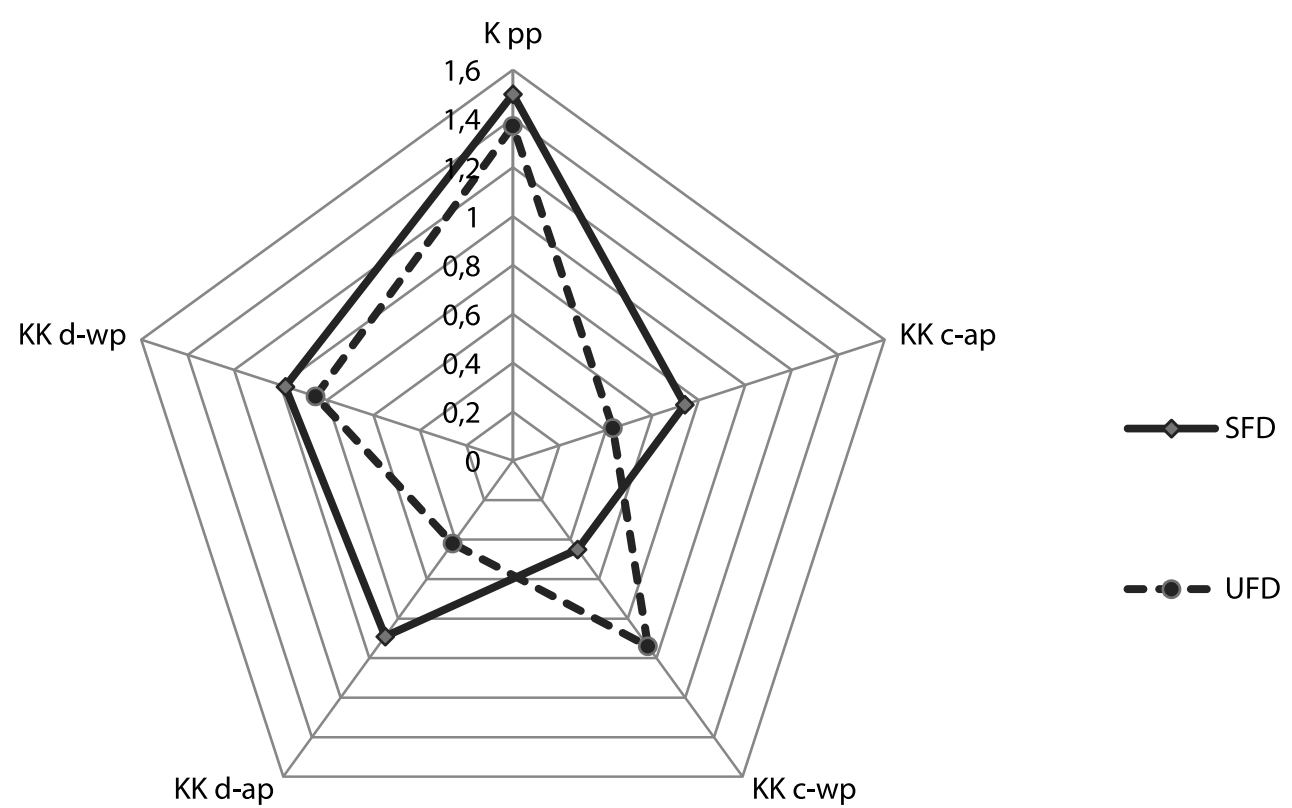

Fig. 7. Correlation of the dependence of mortality and morbidity in the population of the UFD and SFD to industrial pollutions

The active mining operations in the Urals and Siberia correlate with the indicators of disease and mortality (Fig. 7).

Correlations presented in Figure 7 indicate a close correlation between mortality of the population and industrial pollution of the air on the territory of the Siberian Federal District, in the Urals mortality and disease of populations are most highly correlated with pollution of the water. In general, mortality and morbidity in Siberia and the Ural are higher than the average rate in Russia over the recent 10 years.

\section{Conclusions and recommendations}

At first glance, the economy of the Siberian and Ural federal districts can be characterized as dynamic: gross regional product, including the indicator of gross regional product per 1 person of population and the unemployment rate. They are within the natural level.

However, analysis of industry structure over the recent 10 years has shown the increased bias towards mining. There is an annual increase of physical indicators of oil, coal, and natural gas.

Amid the rising volumes of extraction of natural resources, there is a growth of environmental pollution. The results of analysis have showed a close connection between the increase of natural resources exploitation, the environment pollution and the increasing incidence rate of the local population. The example of the UFD and the SFD has demonstrated close correlation of industrial air and water pollution and rates of morbidity and mortality.

At the same time, forests that perform ecological and sanitizing function alongside with oth- ers, cannot cope with the growing volume of existing air pollution, as evidenced by the growing incidence of population dynamics. Expansion of the forest land area due to unused agricultural land will provoke positive tendencies in the industries that use timber as raw material, and will improve the ecology of the regions. In fact, it is already happening as many unused agricultural fields naturally begin to overgrow with woody plants, natural forest restoration is taking place, but this process should become better managed.

Eventually, the buildup of the extractive industries volume, without attention to the environmental aspects of the process will inevitably lead to a reduction in productivity and working-age population, which in turn will be reflected at the GRP.

The way out of this situation would be to create and implement programs to diversify the economy of Siberia and the Ural, support manufacturing, the largest public-private investment projects for the creation of enterprises in agriculture, food and light industry.

In our opinion, a promising direction of diversification of the economy of the Ural Federal District and SFD may be the development of deep wood processing. Proportion of the land covered by forests in these regions is high and makes over $75 \%$.

In view of Russia's accession to the WTO, it is becoming impossible to export out of the country the logging carried out with the use of prison labor (and the cost of this type of product is usually well below market counterparts). Thus, there are clear prerequisites for the development of regional production using local resources in the 
conditions of growing demand for the domes- The implementation of these projects will escatic regional market segments such as bio-en- late the GRP through the creation of new highergy, small distributed power, furniture products, tech jobs without compounding environmental wooden construction, and other consumer goods. burden on the region.

The study was sponsored by RHSF within the scientific project number 12-32-01001a1 "Russian consumer market: diagnostics of industry and rational issues of formation, the development of measures for reduction negative trends".

\section{References}

1. Hochberg M. (2002). Federal Districts of the Russian Federation: analysis and prospects for economical development. Moscow: Finances and Statistics, 360.

2. Long-range forecasting: historical experience and critical analysis. (2009). Abstracts of the participants and XVII Kondratiev readings. Moscow: International Fund of N. Kondratiev. 338.

3. Kondratiev N. (2002). Big cycles environment and the theory of foresight. Moscow: Economics, 300.

4. World economic thought. Through the prism of the century. (2006). 5 Vol. The Co. Editorial Board. 751.

5. http://www.gks.ru/bgd/regl/B11_14s/Main.htm.

\section{Information about the authors}

Eidenzon Dmitriy Valer'evich (Ontario, Canada) — PhD in Technical Science, President, NovoSpark Corporation (York 5298, Vaterloo, Ontario, Canada, e-mail: dmitri.eidenzon@novospark.com).

Ganieva Irina Aleksandrovna (Kemerovo, Russia) - PhD in Economics, Vice-rector on Scientific Work, Kemerovo State Agricultural Institute (5, Markovzeva str., Kemerovo, 650056, Russia, e-mail: ikolesni@mail.ru)

Shpak Natalia Anatol'evna (Yekaterinburg, Russia) - PhD in Economics, Vice-rector for Innovations and International Cooperation, Ural State Forest Engineering University (37, Sibirsky trakt, Yekaterinburg, 620100, Russia, e-mail: shpak@usfeu.ru). 